\title{
PELATIHAN MANAJEMEN KELAS BAGI GURU UNTUK MENCAPAI TUJUAN PEMBELAJARAN
}

\author{
Asih Enggar Susanti ${ }^{1}$ \\ ${ }^{1}$ Universitas Pelitah Harapan \\ asih.susanti@uph.edu
}

\begin{abstract}
Abstrak
Abstrak

Pengelolaan kelas merupakan satu hal yang penting untuk diperhatikan bagi para guru dalam proses belajar mengajar. Hal tersebut dapat memberikan satu kontribusi yang signifikan dalam menciptakan satu lingkungan belajar yaitu kelas yang kondusif baik bagi siswa dan guru pada saat pembelajaran berlangsung. Kegiatan pelatihan ini diadakan melihat kebutuhan peningkatan keterampilan para guru di dalam mengelola kelas pada saat pembelajaran berlangsung. Keterampilan ini sangat diperlukan mengingat salah satu faktor yang mempengaruhi ketercapaian tujuan pembelajaran di kelas adalah kemampuan pengelolaan kelas (classroom management). Oleh karena itu, tujuan Pengabdian kepada Masyarakat (PkM) ini adalah memperkenalkan dan melatihkan praktik-praktik pengelolaan kelas yang efektif kepada guru. Pelatihan ini dilakukan pada bulan Mei hingga Juni 2020 dengan peserta yakni guru dari tingkat TKSMP yang dilakukan secara online. Melalui kegiatan pelatihan ini, menunjukkan hasil bahwa guru dapat memahami materi pelatihan sekalipun media yang digunakan menggunakan video pelatihan yang diunggah dichanel youtube. Terlihat dari evaluasi kegiatan dan penguasaan materi yang diberikan oleh para guru menunjukkan bahwa pelatihan dapat diikuti dengan baik serta guru memiliki pemahaman terhadap materi dengan kategori baik. Simpulan yang dapat diberikan terkait dengan kegiatan PkM ini yaitu melalui pelatihan ini dapat membantu serta memperlengkapi para guru untuk mempersiapkan tahun akademik 2020-2021 dalam hal pengelolaan kelas.
\end{abstract}

Kata Kunci: Manajemen kelas, pelatihan, pembelajaran.

\section{PENDAHULUAN}

Proses pembelajaran dapat berlangsung dengan lancar apabila didukung dengan sebuah lingkungan pembelajaran yang kondusif. Lingkungan tersebut dapat tercipta dengan ditunjang adanya keterampilan guru dalam mengatur kelas yang dimiliki. (Arfani, Junita W. \& Sugiyono, 2014) menjelaskan bahwa manajemen kelas yang efektif dapat membawa pembelajaran menjadi kondusif serta dapat memberikan lingkungan kelas yang dapat membuat instruksi guru menjadi efektif serta jelas. 
Hal ini menjadi satu kekuatan ketika para guru dapat terus memperlengkapi dengan keterampilan mengatur kelas sehingga dapat memperlancar proses belajar dan mengajar yang akan dilakukan dengan para siswa.

Evertson \& Emmer (2015) menyebutkan bahwa kelas yang awalnya baik dapat berakhir kacau dan tak dapat dikendalikan, apabila tidak mendapat perhatian yang cermat dari seorang guru. Hal tersebut semakin memperjelas bahwa keterampilan mengatur atau manajemen kelas menjadi hal yang tidak dapat dipandang sepele oleh para guru. Keterampilan tersebut dapat memberian kontribusi dalam menyediakan pembelajaran yang bermakna bagi para siswa. Bagi guru, kondisi kelas yang diatur dengan baik dapat membawa pembelajaran mencapai tujuan yang telah ditentukan pada awalnya. Selanjutnya dengan mengelola kelas secara teratur guru dapat mengidentifikasi permasalahan baik minor dan mayor yang terjadi dalam lingkup siswa di kelas. Hal ini sejalan dengan (Nugraha, 2018) yang menjelaskan bahwa dengan pengelolaan kelas yang terarah maka guru dapat menciptakan kondisi belajar yang optimal, serta dapat menetralisir gangguan yang terjadi di kelas pada saat proses belajar mengajar berlangsung. Adi (2016) juga menyebutkan bahwa pengaturan kelas yang baik terlihat dari kemampuan guru dalam membuat peserta didik bekerjasama dengan baik dan mampu mengendalikan perbuatan negatif yang menghambat jalannya pembelajaran.

Hal ini menunjukkan pentingnya peranan seorang guru dalam mengatur kelas yang dimilikinya. (Wong, 2009) menjelaskan bahwa seorang guru efektif harus memiliki tiga karakteristik yaitu: 1) memiliki keterampilan mengatur kelas., 2) menguasai materi pembelajaran dan 3) mempraktekan ekspektasi yang positif kepada siswa. Dengan demikian, untuk memulai memiliki salah satu karakteristik tersebut para guru dapat memulai bagian yang bisa dilakukan yaitu guru perlu memiliki kemampuan untuk mengawali kelas secara efektif, merancang disiplin serta merancang dan memiliki prosedur kelas. prosedur kelas sebagai salah satu bagian yang dapat dilakukan untuk mengatur atau membuat kelas menjadi kondusif sepanjang tahun ajaran beralangsung.
Oleh karena itu berkaitan dengan keterampilan mengelola atau manajemen kelas menjadi permasalan mitra yang menjadi fokus pada kegiatan PkM pada semester genap TA 2019-2020 di salah satu sekolah yang berada di Cilegon. Kegiatan Pengabdian kepada masyarakat ini menekankan pada topik yang memfokuskan pada keterampilan memanajemen kelas yakni tentang cara memulai pembelajaran yang efektif, selanjutnya tentang disiplin yang terencana serta prosedur kelas.

Topik diatas menjadi bagian dari fokus mitra dalam mengembangkan rekan rekan guru untuk memiliki keterampilan dalam mengatur kelas sehinga pembelajaran dapat mencapai tujuan yang telah ditetapkan oleh guru. Tujuan dilakukan PkM yang dilakukan di sekolah Mardiyuana Cilegon diharapkan dapat mempelengkapi para guru untuk memiliki afeksi dalam mengajar dengan keterampilan dalam mengatur kelas sehingga dengan kelas yang teratur dan kondusif dapat menunjang kepada tercapainya tujuan pembelajaran yang ditetapkan para guru.

\section{METODE}

Berdasarkan pemahaman di atas, Metode yang dilakukan dalam pelaksanan kegiatan PKM ini adalah dengan memberikan pelatihan kepada guru guru di Sekolah Mardi Yuana Cilegon. Pelatihan guru yang telah dilakukan dengan menggunakan metode need analysis serta modifikasi dari presentasi dari pemateri. Agar pelatihan dapat sesuai dengan kebutuhan, maka sebelum pelaksanaan dilakukan sebuah Analisa kebutuhan dari sekolah. Hal ini sesuai yang dinyatakan oleh (Kroehnert, 2006) bahwa untuk menetapkan kebutuhan pelatihan maka perlu dilakukan identifikasi gap atau permasalahan yang terjadi dilingkup wilayah pengetahuan, keterampilan dan sikap. Need analysis tersebut menjadi metode awal sebelum dilakukannya pelatihan kepada rekan rekan guru dengan mengumpulkan informasi dari para pemimpin di sekolah.

Selanjutnya pelatihan dilakukan dengan cara memberikan materi secara online kepada para guru. Metode yang gunakan dengan menjelaskan secara ceramah melalui video presentasi. Metode presentasi dengan ceramah dipilih oleh para pemateri mengingat dalam kondisi pandemic, kegiatan

$$
\text { Pendidikan } 706
$$


pelatihan tidak dapat dilakukan secara langsung melainkan dengan menggunakan media secara online. Dengan demikian metode ini diharapkan dapat menjembatani proses pelatihan yang dilakukan secara online. (Eggen, 2012) menjelaskan bahwa salah satu kelebihan metode ceramah dapat dilihat dari fleksibelitas karena dapat diterapkan pada nyaris setiap bidang materi serta dilihat berdasarkan keterbatasan waktu maka perencanaan untuk mengatur materi dengan metode ini dapat dilakukan dengan efisien.

Melihat situasi dalam kondisi pandemik maka dengan adanya Analisa kebutuhan yang kemudian dilanjutkan dengan memberikan pelatihan secara online lewat metode ceramah menjadi salah satu cara yang dapat dilakukan pada kegiatan PkM yang telah dilaksanakan pada bulan Mei tahun 2020 lalu.

Proses persiapan dilakukan oleh tim yang terdiri dari empat rekan dosen pemateri yang dibantu dengan lima Mahasiswa. Pelaksanaan dilakukan dengan membuat materi, merekam serta mengupload pada channel youtube, selanjutnya memberikan link materi kepada para leader sekolah. Secara teknis di sekolah leader di sekolah.

\section{HASIL DAN PEMBAHASAN}

Secara umum proses pelaksanaan pelatihan diikuti lebih dari 50 rekan guru dari jenjang TK sampai SMP. Sebagai bentuk bagian melihat efektifitas kegiatan pelaksanaan pegabdian masyarakat mengenai pelatihan pengelolaan kelas maka para peserta diberikan kesempatan untuk mengisi evaluasi kegiatan. Evaluasi ini menjadi salah satu langkah bagi guru untuk mendapatkan sertifikat pelatihan, selanjutnya bagi kami menjadi satu langkah untuk mendapatkan umpan balik terkait dengan kegiatan yang telah berlangsung. Berdasarkan evaluasi yang telah diisi, berikut ini adalah hasil survey terhadap para peserta pelatihan yakni berjumlah 35 reakn guru yang mengisi, yang terdiri dari 15 guru TK, 10 guru SD dan 19 guru SMP.

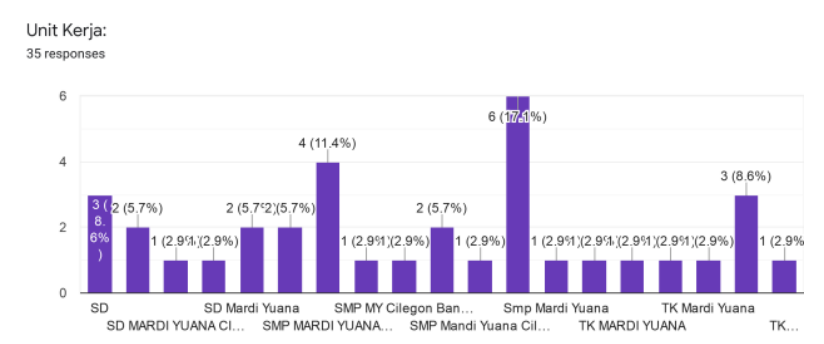

Form evaluasi pelatihan yang telah diisi oleh para reakn guru diharapkan dapat memberikan umpan balik selama proses pelatihan berlangsung. Evaluasi ini berkaitan dengan kegiatan secara keseluruhan serta evaluasi dalam hal pemahaman materi yang telah diikuti.

\subsection{Hasil Kegiatan}

Berikut ini akan diuraikan hasil dari pelaksanana kegiatan pelatihan pegelolaan kelas yang telah dilakukan secara online. Hasil kegiatan ini mencakup dari evaluasi pelaksanaan serta tingkat penguasaan materi dari para rekan guru setelah mengikuti kegiatan pelatihan.

\subsubsection{Pemahaman Materi Peserta Pelatihan}

Evaluasi pertama dilakukan untuk melihat sejauh mana pemahaman yang dapat dimiliki oleh para peserta pelatihan dalam mempelajari materi pelatihan yang ada. Berikut ini adalah hasil dari survei tentang pemahaman materi yang dimiliki oleh guru:

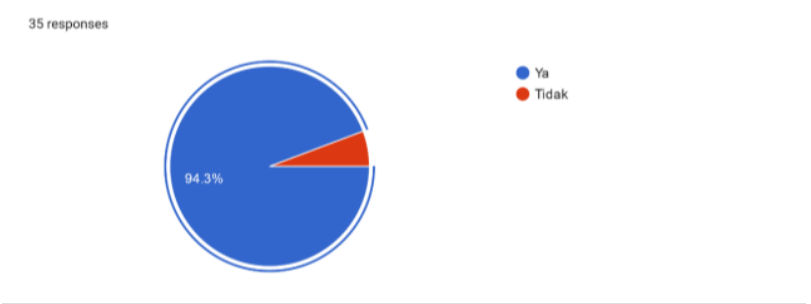

Berdasarkan grafik diatas dapat dijumpai bahwa 94,3\% guru dapat memahami materi pelatihan dengan mudah. Dengan demikian dapat dipahami bahwa secara keseluruhan seluruh peserta pelatihan dapat memahami materi dengan kategori sangat baik.

Pendidikan 


\subsubsection{Keterampilan Pemateri/Trainer dalam Menyampaikan Materi}

Berikut ini adalah hasil dari survei mengenai cara pemateri/trainer dalam menyampaikan materi pelatihan kepada rekan rekan guru.

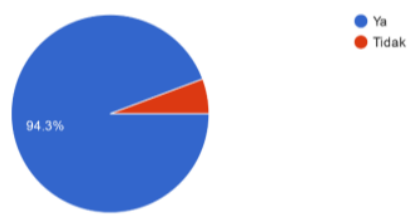

Berdasarkan grafik diatas dapat dijumpai bahwa 94.3\%\% peserta mudah memahami cara para trainer dalam menyampaikan materi. Secara keseluruhan maka dapat disimpulkan bahwa seluruh pemateri dapat membawakan dan menyampaikan materi pelatihan dengan kategori sangat baik.

\subsubsection{Penggunaan Media Pelatihan secara Online}

Berikut ini adalah hasil dari survei mengenai penggunaan media pelatihan secara online menunjukkan bahwa $80 \%$ peserta tidak bermasalah dalam mengikuti pelatihan. Data tersebut dapat dilihat pada grafik berikut ini:

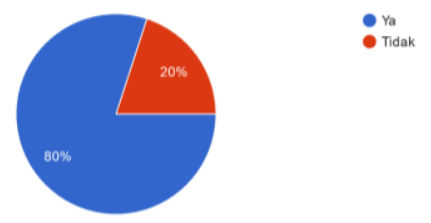

Berdasarkan grafik diatas dapat dijumpai bahwa $80,9 \%$ guru dapat mempelajari materi secara baik dengan menggunakan media pembelajaran online Sebaliknya, guru yang tidak dapat mempelajari materi secara baik sejumlah $19,1 \%$. Secara keseluruhan maka pada penggunaan media pembelajaran online masih dalam kategori baik.

\subsubsection{Motivasi para guru dalam pelatihan}

materi pelatihan diberikan seara online, maka secara tidak langsung memberikan ruang kepada para guru untuk menjadi seorang pembelajar mandiri. Oleh sebab itu motivasi juga sangat diperleukan dalam hal ini. Survei berikut ini menunjukkan tentang motivasi para guru dalam pelatihan

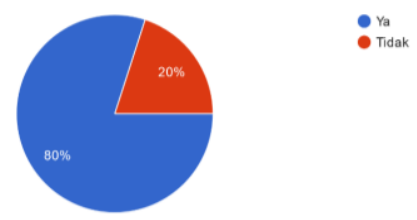

Berdasarkan grafik di atas dapat dijumpai bahwa 80 $\%$ guru memiliki motivasi untuk mengikuti pelatihan. Sebaliknya, guru yang tidak memiliki motivasi sejumlah 20\%, meskipun dalam hal ini angka tersbut tidak disertai dengan keterangan dari para guru yang menjadi faktor kurang atau tidak termotivasinya mereka dalam mengikuti pelatihan. Berdasarkan data di atas dapat disimpulkan bahwa motivasi para guru dalam kategori baik.

\subsubsection{Kendala dalam mengikuti materi secara online}

Survei berikut ini dilakukan untuk mengidentifikasi kendala yang dialami oleh guru dalam mengikuti pelatihan secara online.

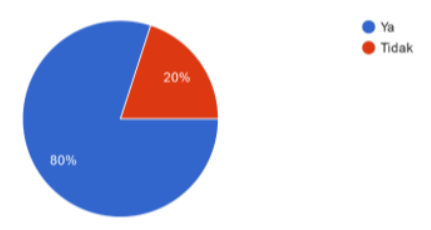

Berdasarkan grafik di atas dapat dijumpai bahwa $80 \%$ guru tidak memiliki kendala dalam mengikuti materi pelatihan secara online. Sebaliknya, guru yang memiliki kendala sejumlah 20\%. Secara keseluruhan maka mengenai kendalan dalam mengikuti pelatihan secara online masih dalam kategori baik.

Evaluasi yang dilakukan tidak hanya terbatas pada evaluasi pelaksanaan pelatihan secara online, namun juga mencakup pemahaman materi yang dimiliki

$$
\text { Pendidikan }
$$


oleh guru dengan materi pelatihan yang telah diikuti selama pelatihan secara mandiri. Berikut ini merupakan beberapa hasil evaluasi terkait dengan materi pelatihan.

\subsubsection{Kelas yang berjalan baik, bergantung dari guru mengajarkan prosedur kelas.}

Pada survei ini menunjukkan respon dari para guru tentang bagiamana peranan guru dalam kelas untuk mengelola sebagai lingkungan belajar yang kondusif dengan baik.

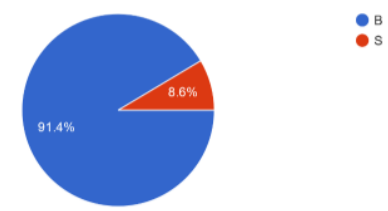

Berdasarkan grafik di atas dapat dijumpai bahwa 91.4\% guru setuju bahwa kelas yang berjalan dengan baik, bergantung dari guru yang mengajarkan prosedur kelas. Secara keseluruhan maka pemahaman guru mengenai pertanyaan ini dalam kategori sangat baik. Materi dipahami dengan begitu baik bahwa guru menjadi kunci dalam menciptakan kondisi kelas yang baik yakni guru perlu mengajarkan prosedur kelas dengan jelas kepada siswa. Dengan demikian siswa dapat mengikuti prosedur serta peraturan kelas yang berlaku.

\subsubsection{Prosedur yang digunakan dapat meningkatkan siswa untuk fokus dalam mengerjakan tugas dan mengurangi keributan dalam kelas.}

Berikut ini adalah hasil dari survei mengenai jawaban dari para guru tentang prosedur kelas yang dapat digunakan untuk meningkatkan fokus siswa dalam mengerjakan tugas dan mengurangi keributan dalam kelas.

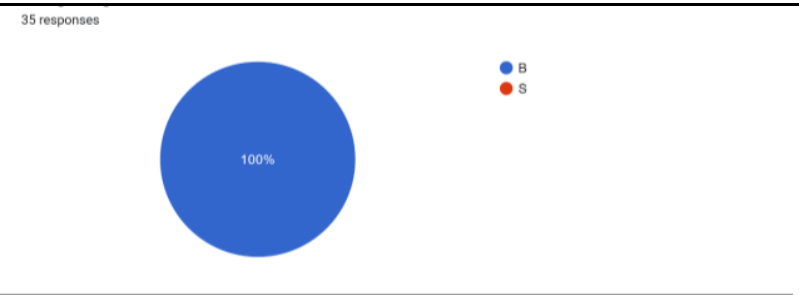

Berdasarkan grafik di atas dapat dijumpai bahwa $100 \%$ guru setuju bahwa prosedur kelas dapat digunakan untuk meningkatkan fokus siswa dalam mengerjakan tugas dan mengurangi keributan dalam kelas. Secara keseluruhan maka pemahaman guru mengenai pertanyaan ini masih dalam kategori sangat baik.

\subsubsection{Guru efektif tidak perlu melakukan perencanaan dalam menetapka aturan-aturan kelas.}

Berikut ini adalah hasil dari survei mengenai jawaban dari para guru tentang perencanaan dalam menetapkan aturan-aturan kelas. Hasil menunjukkan bahwa $94.3 \%$ rekan guru sependapat bahwa ada peranan guru dalam merancang peraturan peraturan kelas.

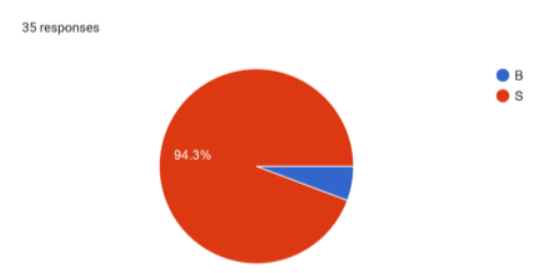

Dengan demikian dapat disimpulkan bahwa pemahaman materi yang dimiliki guru tentang bagaimana merancang disiplin efektif dengan merancang peraturan kelas dapat dikategorikan sangat baik.

\subsubsection{Konsekuensi dapat diartikan sebagai hukuman. \\ Berikut ini adalah hasil dari survei mengenai jawaban dari para guru tentang konsekuensi yang dapat diartikan sebagai hukuman.}

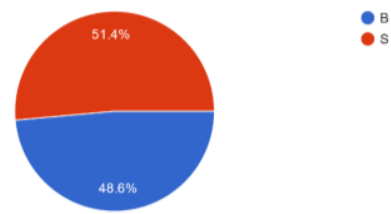


Berdasarkan grafik di atas dapat dijumpai bahwa $55,3 \%$ guru setuju bahwa konsekuensi dapat diartikan sebagai hukuman. Sebaliknya, guru yang tidak setuju sejumlah $44,7 \%$. Secara keseluruhan maka pemahaman guru mengenai pertanyaan ini dalam kategori kurang baik.

\subsubsection{Harapan diberikan ketika murid melakukan perbuatan-perbuatan baik sesuai dengan kesepakatan kelas.}

Berikut ini adalah hasil dari survei mengenai jawaban dari para guru tentang harapan yang diberikan kepada murid ketika mereka melakukan perbuatan-perbuatan baik telah sesuai dengan harapan yang sudah disepakati kelas.

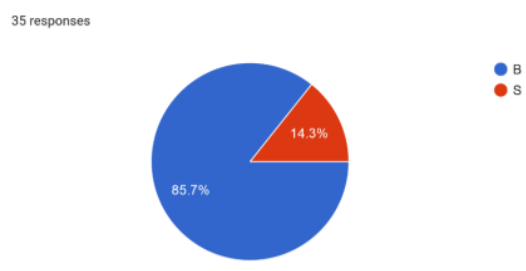

Berdasarkan grafik di atas dapat dijumpai bahwa $89,4 \%$ guru menjawab benar bahwa harapan yang diberikan kepada murid ketika mereka melakukan perbuatan-perbuatan baik telah sesuai dengan harapan yang sudah disepakati kelas. Sebaliknya, guru yang menjawab tidak benar sejumlah 10,6\%. Secara keseluruhan maka pemahaman guru mengenai pertanyaan ini dalam kategori baik.

\subsubsection{Guru efektif memulai kelas langsung dengan memberikan tugas, bukan mengabsen.}

Berikut ini adalah hasil dari survei mengenai jawaban dari para guru tentang guru yang efektif adalah guru yang memulai kelas langsung dengan memberikan tugas, bukannya mengabsen
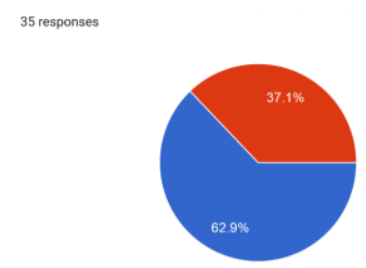

$:$ :

Berdasarkan grafik di atas dapat dijumpai bahwa $68,1 \%$ guru menjawab benar bahwa guru yang efektif adalah guru yang memulai kelas langsung dengan memberikan tugas, bukannya mengabsen. Sebaliknya, guru yang menjawab tidak benar sejumlah 31,9\%. Secara keseluruhan maka pemahaman guru mengenai pertanyaan ini dalam kategori cukup baik.

Hasil survei diatas dalam hal pemahaman materi yang diterima oleh rekan rekan guru, pada dasarnya dapat menjadi modal awal dari sisi pengetahuan untuk mendesain kelas yang kondusif.

Hal ini menjadi langkah awal ketika guru mulai memahami bahwa memulai pembelajaran harus dengan kegiatan efektif, tidak berhenti dengan melakukan absensi kepada siswa. Selanjutnya guru dapat merancang kegiatan disiplin kelas yang efektif, sehingga ketika proses pembelajaran tidak berhenti hanya untuk mendisiplinkan siswa, melainkan siswa dikenalkan pada prosedur dan peraturan kelas. Dengan demikian dapat menunjang pembelajaran dengan kondusif sehingga dapat mencapai tujuan pembelajaran yang telah direncanakan oleh guru. Pengelolaan kelas yang kondusif akan mendorong adanya sebuah pengelolaan pada pembelajaran yang efektif. Menurut Tsui 2002 dalam (Hue \& Li, 2008) menjelaskan bahwa melalui pengelolaan kelas maka akan berdampak pada guru dalam manajemen pembelajaran yang lebih baik. Mengelola kelas untuk pembelajaran yang lebih efektif, dan para siswa dapat lebih terlibat dalam pembelajaran, kelas menjadi ruang belajar yang menyenangkan dan menantang bagi siswa sekaligus peka terhadap kebutuhan dan tujuan anak anak dalam pendidikan. Oleh karena itu, ketika guru mengelola kelas dengan efektif maka proses pembelajaran yang akan 
membawa pada pencapaian tujuan yang telah guru tetapkan diawal.

\section{KESIMPULAN}

Berdasarkan uraian pada bab sebelumnya maka kesimpulan bahwa peserta pelatihan dapat mengikuti serta memahami isi kegiatan pelatihan dengan baik sebagai langkah awal dalam mengelola kelas yang efektif sehingga dapat mencapai tujuan pembelajaran yang direncanakan guru. Para guru memahami bahwa guru berperan penting dalam menciptakan kelas yang kondusif dengan memulai pembelajaran dengan efektif, merancangkan disiplin secara efektif serta mengajarkan prosedur kelas sebagai langkah untuk mengelola kelas dengan efektif dengan demikian dapat menunjang proses kegiatan pembelajaran untuk mencapai tujuan yang telah direncanakan.

Saran

Setelah kegiatan PkM pelatihan bagi para guru dilaksanakan terdapat beberapa saran yang diperhatikan sehingga dapat menjadi bahan masukan serta perbaikan kedepannya untuk lebih baik.

1. Pelatihan dengan menggunakan media online menjadi peluang serta sekaligus menjadi tantangan. Oleh karena itu alangkah lebih baik pelaksanaan dilakukan secara webinar sehingga guru dapat mengikuti penjelasan materi pelatihan dari pemateri secara virtual. Dengan demikian apabila terdapat pertanyaan maka dapat disampaikan kepada pemateri secara langsung.

2. Dalam hal keikutsertaan guru, apabila kedepannya dilakukan dengan webinar secara langsung maka dapat memaksimalkan partisipasi dari seluruh guru.

\section{UCAPAN TERIMAKASIH}

Kami mengucapkan terima kasih atas dukungan yang diberikan oleh Universitas Pelita Harapan dalam segi dukungan moril serta materi pendanaan pada kegiatan Pengabdian kepada Masyarakat yang telah dilakukan dengan nomor kegiatan PM037/FIP/I/2020.

\section{REFERENSI}

Adi, S. S. (2016). Classroom management. Malang: Universitas Brawijaya Media

Arfani, Junita W., \& Sugiyono. (2014). MANAJEMEN KELAS YANG EFEKTIF: PENELITIAN DI TIGA SEKOLAH MENENGAH ATAS. Jurnal Akuntabilitas Manajemen Pendidikan, 2(1), 44-57. https://doi.org/10.21831/amp.v2i1.2408

Eggen, P. . K. D. (2012). Strategi dan model pembelajaran: mengajarkan konten dan keterampilan berpikir Paul Eggen, Don Kauchak (6th ed.). PT Indeks.

Hue, M., \& Li, W. (2008). Classroom Management. Hong Kong University Press. https://doi.org/10.5790/hongkong/9789622098 886.001 .0001

Kroehnert, G. (2006). Basic training for trainers : a handbook for new trainers (3rd ed.). McGrawHill.

Nugraha, M. (2018). MANAJEMEN KELAS DALAM MENINGKATKAN PROSES PEMBELAJARAN. Tarbawi: Jurnal Keilmuan Manajemen Pendidikan, 4(01), 2744.

http://jurnal.uinbanten.ac.id/index.php/tarbawi

Wong, H. (2009). The first days of school: how to be an effective teacher ([New ed.].). Harry $\mathrm{K}$. Wong Publications Inc.

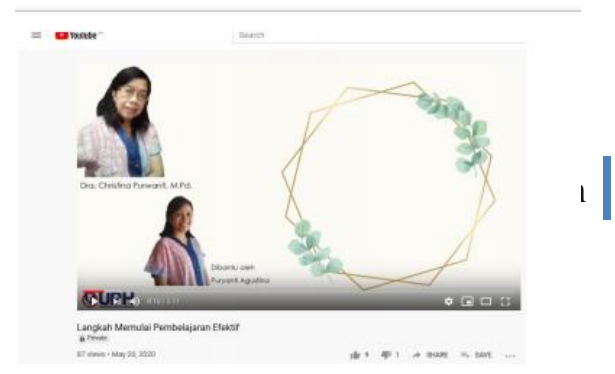

